\title{
Absence of Trichinella spiralis in swine carcasses slaughtered in the midwestern Region of Paraná State, Brazil
}

\section{Ausência de Trichinella spiralis em carcaças de suínos abatidos na região centro-oeste do Estado do Paraná, Brasil}

\author{
Amanda Keller Siqueira ${ }^{1 *}$; Vanessa Gomes da Silva²; Isabelle Dangui Ferro ${ }^{3}$; \\ Ricardo Antonio Freitas ${ }^{4}$; Alexandre Giesel ${ }^{5}$
}

\section{Highlights:}

Pig carcass screening by digestion assay is the gold standard method for diagnosing Trichinella spiralis. Brazil is considered to have no epidemiological risks for human trichinellosis.

Pigs kept under controlled housing systems are not a source of T. spiralis in Brazil.

\begin{abstract}
Trichinella spiralis causes severe infections in humans, resulting in various clinical symptoms and even death, in several countries worldwide. Human trichinellosis has been reported in 55 countries, and mainly affects certain ethnic groups and tourists. It is caused by the ingestion of raw, undercooked meat or pork, or their by-products containing parasitic larvae. Infections in swine especially occur due to the parasitic contamination of food containing animal products, predation by rodents and other animals infected with T. spiralis, and due to the frequent habit of cannibalism in intensive production systems. This study aimed to evaluate the prevalence of $T$. spiralis in pig carcasses from a slaughterhouse located in the midwestern region of Paraná State, Brazil. Pools of $100 \mathrm{~g}$ of diaphragm, containing at least $1 \mathrm{~g}$ of tissue from each test animal, were collected, ground, and subjected to acid digestion with pepsin $(1: 10,000)$ and $25 \%$ hydrochloric acid. Sampling was performed in accordance to the methodology recommended by the European Union. All the 735,902 samples collected between 2010 and 2013, and in 2018, were negative for Trichinella spp. larvae. The pigs came from 483 farms from 90 municipalities from the three states of southern Brazil (Paraná, Santa Catarina and Rio Grande do Sul). The absence of the parasite in different animal species, reported by surveys conducted in Brazil, could confirm the country as free from trichinellosis. Although T. spiralis is not endemic to Brazil, it is necessary to subject the meat of adult pigs slaughtered here and exported to other countries to inspections and parasitological examinations. It is therefore necessary to continually inspect pig carcasses for $T$. spiralis in slaughterhouses worldwide.
\end{abstract}

Key words: Trichinellosis. Nematode. Inspection. Meat trade.

\footnotetext{
1 Médica Veterinária, Dr ${ }^{\mathrm{a}}$ em Medicina Veterinária Preventiva, Faculdade de Medicina Veterinária e Zootecnia, Universidade Estadual de São Paulo, FMVZ/UNESP, Botucatu, SP, Brasil. E-mail: kellersiqueira@hotmail.com

2 Médica Veterinária, Universidade Federal da Fronteira Sul, UFFS, Laranjeiras do Sul, PR, Brasil. E-mail: vanessa.silva@uffs. edu.br

3 Médica Veterinária, Médica Veterinária Oficial, SIF 119, Laranjeiras do Sul, PR, Brasil. E-mail: isabelle_danguiferro1976@ hotmail.com

4 Médico Veterinário, Auditor Fiscal Federal Agropecuário, SIF 119, Laranjeiras do Sul, PR, Brasil. E-mail: ricardo.freitas@ agricultura.gov.br

$5 \mathrm{Eng}^{\mathrm{O}} \mathrm{Agr}^{\mathrm{o}}$, Dr. em Produção Vegetal, Centro de Ciências Agroveterinárias, Universidade do Estado de Santa Catarina, CAV/ UDESC, Lages, SC, Brasil. E-mail: alexandregiesel@gmail.com

Author for correspondence
} 


\section{Resumo}

Trichinella spiralis causa infecções graves em humanos, resultando em vários sintomas clínicos e até morte, em vários países do mundo. A triquinelose humana foi relatada em 55 países e afeta principalmente certos grupos étnicos e turistas. É causada pela ingestão de carne crua ou malpassada, ou seus subprodutos contendo larvas parasitas. As infecções em suínos ocorrem principalmente devido à contaminação parasitária de alimentos contendo produtos de origem animal, predação de roedores e outros animais infectados com T. spiralis, além do hábito frequente de canibalismo em sistemas de produção intensiva. Este trabalho objetivou avaliar a prevalência de T. spiralis em carcaças de suínos de um abatedouro localizado na região centro-oeste do Estado do Paraná. Conjuntos de $100 \mathrm{~g}$ de diafragma, contendo pelo menos $1 \mathrm{~g}$ de tecido de cada animal testado, foram coletados, triturados e submetidos a digestão ácida com pepsina (1:10.000) e ácido clorídrico a $25 \%$. A amostragem foi realizada de acordo com a metodologia recomendada pela União Europeia. Todas as 735.902 amostras coletadas entre 2010 e 2013, e em 2018, foram negativas para larvas de Trichinella spp. Os suínos foram provenientes de 483 fazendas, de 90 municípios, dos três estados do sul do Brasil (Paraná, Santa Catarina e Rio Grande do Sul). A ausência do parasita em diferentes espécies animais, relatada por pesquisas realizadas no Brasil, poderia confirmar o país como livre de triquinelose. Embora T. spiralis não seja endêmica no Brasil, é necessário submeter a carne de suínos adultos abatidos aqui e exportados para outros países, a inspeções e exames parasitológicos. É, portanto, necessário inspecionar continuamente carcaças de suínos para $T$. spiralis em abatedouros de todo o mundo.

Palavras-chave: Triquinelose. Nematoide. Inspeção. Mercado de carne.

Trichinella spp. are nematodes that do not have an environmental development phase, and are considered to be obligatory parasites thriving in the muscles of carnivorous, omnivorous, and accidental hosts, causing economic problems in terms of food production and public health (Gottstein, Pozio, \& Nöckler, 2009; Pozio, 2015). Several parasitic diseases can be transmitted to humans due to the consumption of contaminated food produced by the improper breeding of animals and/or erroneous food handling (Pozio, 2015).

In humans, T. spiralis causes severe infections, primarily resulting in immunological, pathological, and metabolic disorders, that give rise to various clinical symptoms and even death, in several countries across the world (Gottstein et al., 2009). Trichinellosis is caused by parasites that are mostly distributed among domestic and wild animals. Human parasitosis has been reported in 55 countries, and mainly affects ethnic groups and tourists (Pozio, 2018). There are no reports of the parasite in Brazilian pig herds; however, it is known that epidemiological surveillances performed by constant parasitological examinations is a key factor in the control programs.

Infections in swine primarily occur due to the consumption of parasitic contamination of food containing animal products, due to predation by rodents and other animals infected with $T$. spiralis, and due to the habit of cannibalism that is frequent in intensive production systems (Gamble, 1997).

Murrell (2016) reports that the global incidence of human trichinellosis has been declining or stabilizing since the mid-twentieth century. Although T. spiralis is not endemic to Brazil, it is necessary to inspect and perform parasitological examinations of the meat of adult pigs slaughtered here that are imported from other countries, especially from the European Union (Pozio, 2014).

The aim of this study was to evaluate the prevalence of $T$. spiralis in pig carcasses from a slaughterhouse located in the midwestern region of the state of Paraná, Brazil, between 2010 and 2013, and in 2018, in accordance to the certification standards of the countries of the European 
Community, and also those of Russia, Argentina, and Uruguay, for the importation of Brazilian pork.

A total of $1,386,067$ pigs were slaughtered between 2010 and 2013, and in 2018, in an abattoir located in the midwestern region of the state of Paraná in Brazil. Samples from 735,902 (53.09\%) pig carcasses were randomly collected by the Federal Inspection Service (SIF). The pigs came from 483 farms, from 90 municipalities, from the states of Paraná (2430'00”S, 51²0’00”W), Santa Catarina $\left(27^{\circ} 33^{\prime} 00^{\prime \prime} \mathrm{S}, 50^{\circ} 00^{\prime} 00^{\prime \prime} \mathrm{W}\right)$, and

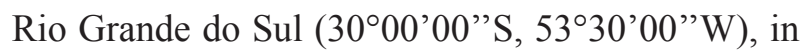
Southern Brazil. These states are in the south of the Tropic of Capricorn, where a subtropical climate predominates, and the annual average temperature ranges between $14^{\circ} \mathrm{C}$ and $22^{\circ} \mathrm{C}$.

The samples were collected immediately after slaughter and kept in separately identifiable containers. The samples consisted of a mixed pool of $100 \mathrm{~g}$ of diaphragm muscle, containing at least 1 $\mathrm{g}$ of tissue from each of the test animals. Sampling was performed in accordance to the methodology recommended by the European Union (Commission regulation $\left.n^{\circ} 2015 / 1375,2015\right)$. The pools of samples were ground, subjected to acid digestion with pepsin $(1: 10,000)$ and $25 \%$ hydrochloric acid, and kept on a magnetic stirrer at a temperature of $44^{\circ} \mathrm{C}$ to $46^{\circ} \mathrm{C}$ for 30 minutes. Following complete digestion, the sample was filtered into a new flask, and allowed to stand for 30 minutes. Finally, the supernatant was discarded and the sample was examined after 10 minutes under a microscope, at a magnification of $40 \mathrm{X}$.

If a combined sample, represented by a mixed pool of $100 \mathrm{~g}$ of diaphragm muscle containing at least $1 \mathrm{~g}$ of sample from each test animal, presented positive or doubtful results, fresh $20 \mathrm{~g}$ samples of diaphragm muscle were to be taken from not more than 5 animals in the positive pool, for generating new sample pools of $100 \mathrm{~g}$ that were to be subjected to acid digestion and analyses. Similarly, from each of these positive sample pools comprising tissues from 5 animals, fresh samples of $20 \mathrm{~g}$ were to be collected from each animal in the positive pool and re-analyzed. If parasites were found in the samples, they were to be kept in $90 \%$ ethyl alcohol for conservation and subsequent identification of the species in a reference laboratory.

Since the exportation company did not export pork to countries requiring negative certification of the presence of the parasite between 2014 and 2017, the presence of $T$. spiralis was not investigated in this period. Besides, Brazil does not require certification for the sale of pork in the internal markets.

All the samples from the 735,902 pigs slaughtered between 2010 and 2013, and in 2018, were found to be negative for Trichinella spp. larvae. This result agreed with the results of other studies conducted in Brazil. Souza, Sposito and Merlini (2013) examined 9,520 pigs slaughtered in the northwestern region of the state of Paraná, and reported the absence of Trichinella spp. larvae in all the diaphragm, tongue, and masseter tissue samples collected from each of the test animals. Daguer, Geniz and Santos (2005) examined 3,774 adult pigs, slaughtered under federal inspection, from 68 municipalities in the southern regions of the city of Palmas in the state of Paraná, Brazil, and reported the absence of parasitic larvae in all the animals examined. Similar to the present study, these studies also employed the technique of acid digestion for studying the presence of $T$. spiralis larvae in the tissue samples.

Pozio (2014) reported that Argentina can be considered as the only country in South America endemic for Trichinella spp., since the nematode is only detected in domestically reared pigs, and is no longer detectable in the industrial production systems of Chile. According to García, Mora, Torres, Jercic and Mercado (2005), the first record of human trichinellosis in Chile was associated with the consumption of wild boar.

Despite the absence of $T$. spiralis in pigs, studies have investigated the presence of $T$. spiralis larvae in the muscles of horses slaughtered in the country. 
In a study by Evers et al. (2012), none of the samples collected from the 398 equines from six different Brazilian states showed the presence of the parasite. Similarly, Salazar and Salotti-Souza (2017) reported the absence of $T$. spiralis larvae in the muscles of 14,852 horses slaughtered in Araguari of the state of Minas Gerais in Brazil. In both the aforementioned studies, the authors employed the technique of enzymatic digestion for analyzing the presence of the larvae in the masseter muscle of the test animals.

However, the study conducted by Giessen et al. (2013) in Netherlands demonstrated that artificial digestion may not be able to detect the presence of $T$. spiralis when the pig carcass is contaminated with a few larvae, since they diagnosed a case of trichinellosis in a Dutch patient who had consumed inspected meat. Yang et al. (2016) demonstrated that the use of serological tests may promote the detection of the parasite circulating among humans and animals. It is therefore important to apply diagnostic techniques, along with continuous and meticulous evaluation processes, for inspecting pig carcasses in slaughterhouses across the world.

Wild boar is considered to be an exotic animal in Brazil, and with the increase in the number of wild boar attacks to humans, pets, farm animals, and native wild animals, the Brazilian government (Instrução Normativa $n^{\circ} 3$, 2013) has authorized population control of the free-living Sus scrofa throughout the national territory. Therefore, the meat of wild boars may be consumed without proper cooking, without sanitary control or inspection services, and may represent an important source of infection by several agents, including T. spiralis, in Brazil.

The absence of the parasite in different animal species, reported by surveys conducted in Brazil, confirms that the country is free from trichinellosis, as published by the World Organisation for Animal Health (World Organisation for Animal Health [OIE], 2019). Nevertheless, researchers opine that the complete eradication of Trichinella spp. is practically impossible, since the agent migrates among wild animal populations (Pozio, 2014). Thus, controlling the circulation of the agent among domesticated animals should be continually practiced by veterinary inspection services, and the Brazilian population should be educated in these matters (Pozio, 2018). Since Brazil is considered to be devoid of epidemiological risks, pork exportation indices to different consumer centers, especially to those countries that have specific importation requirements, can be improved (Commission regulation $\mathrm{n}^{\circ}$ 2015/1375, 2015; OIE, 2019).

In agreement with the studies that reported the absence of T. spiralis in domestic pigs, Murrell (2016) demonstrated that the meat of wild animals was the primary cause for human trichinellosis across the world, despite the implementation of Trichinella spp. control programs in industrial pig systems. One Health precepts represents the most promising approach for understanding the pathogenesis and epidemiology of trichinellosis, including the generation of subsidies for treatment, diagnosis and, particularly, for preventing the infection.

The results of this study suggest that pigs from the farms in the three states in Southern Brazil, Paraná, Santa Catarina, and Rio Grande do Sul, which were examined in this study, are not parasitized by $T$. spiralis, and do not have health risks to consumers. However, other investigations must be continually conducted, and should employ other diagnostic techniques, such as serological tests, in order to support the possible absence of trichinellosis in the southern and other regions of Brazil. Nevertheless, even if there are no reports on the circulation of the parasite in Brazil, it is important to increase the awareness of the producers about proper animal management, since preserving the Trichinella spp.free status will project the country as a leading producer and exporter of pork across the world. Additionally, increasing public awareness of the risks of consuming raw or undercooked pork or wild boar, and especially the lack of sanitary inspection, will be advantageous in the context of public health. 


\section{References}

Commission regulation $n^{\circ} 2015 / 1375$, of 10 August 2015. Laying down specific rules for Trichinella in meat. Retrieved from https://eur-lex.europa.eu/legalcontent/PT/TXT/HTML/?uri=CELEX:32015R1375 \& from $=\mathrm{pt}$

Daguer, H., Geniz, P. V., \& Santos, A. V. (2005). Ausência de Trichinella spiralis em suínos abatidos em Palmas, Estado do Paraná, Brasil. Ciência Rural, 35(3), 660663. doi: 10.1590/S0103-84782005000300028

Evers, F., Garcia, J. L., Navarro, I. T., Freitas, J. C., Bonesi, G. L., Benitez, A. N., . . Freire, R. L. (2012). Zoonosis of public health interest in slaughtered Brazilian equidae. Semina: Ciências Agrárias, 33(3), 32233232. doi: 10.5433/1679-0359.2012v33Supl2p3223

Gamble, H. R. (1997). Parasites associated with pork and pork products. Revue Scientifique et Technique de l'Office Internationale des Epizooties, 16(2), 496506.

García, E., Mora, L., Torres, P., Jercic, M. I., \& Mercado, R. (2005). First record of human trichinosis in Chile associated with consumption of wild boar (Sus scrofa). Memórias do Instituto Oswaldo Cruz, 100, 17-18. doi: 10.1590/S0074-02762005000100003

Giessen, J. van der, Franssen, F., Fonville, M., Kortbeek, T., Beckers, P., Tolsma, P., . . . Takumi, K. (2013). How safe is the meat inspection based on artificial digestion of pooled samples for Trichinella in pork? A scenario from wildlife to a human patient in a nonendemic region of Europe. Veterinary Parasitology, 194(2-4), 110-112. doi: 10.1016/j.vetpar.2013.01.032

Gottstein, B., Pozio, E., \& Nöckler, K. (2009). Epidemiology, diagnosis, treatment, and control of trichinellosis. Clinical Microbiology Reviews, 22(1), 127-145. doi:10.1128/CMR.00026-08
Instrução Normativa $n^{\circ} 3$, de 31 Janeiro 2013. Decreta a nocividade do Javali e dispõe sobre o seu manejo e controle. Recuperado de http://arquivos.ambiente. sp.gov.br/fauna/2014/07/IN_Ibama_03_2013.pdf

Murrell, K. D. (2016). The dynamics of Trichinella spiralis epidemiology: out to pasture? Veterinary Parasitology, 231, 92-96. doi: 10.1016/j. vetpar.2016.03.020

Pozio, E. (2014). Searching for Trichinella: note all pigs are created equal. Trends in Parasitology, 30(1), 4-11. doi: 10.1016/j.pt.2013.11.001

Pozio, E. (2015). Trichinella spp. imported with live animals and meat. Veterinary Parasitology, 213(12), 46-55. doi: 10.1016/j.vetpar.2015.02.017

Pozio, E. (2018). Trichinella and other foodborne parasites. In Y. R. Ortega \& C. R. Sterling (Eds.). Foodborne Parasites (Chap. 9,pp. 175-215). Springer International Publishing. Retrieved from https://link. springer.com/chapter/10.1007/978-3-319-67664-7 9

Salazar, A. F. N., \& Salotti-Souza, B. M. (2017). Avaliação da presença de Trichinella spiralis em equinos abatidos em Araguari. Higiene Alimentar, 31(268-269), 102-105.

Souza, E. O., Sposito, P. H., \& Merlini, L. S. (2013). Pesquisa de Trichinella spiralis em suínos abatidos na região noroeste do estado do Paraná, Brasil. Revista Brasileira de Higiene e Saúde Animal, 7(2), 225-232. doi: 10.5935/1981-2965.20130020

World Organisation for Animal Health. (2019). Information database. Retrieved from http:// www.oie.int/wahis_2/public/wahid.php/ Countryinformation/Animalsituation

Yang, Y., Cai, Y. N., Tong, M. W., Sun, N., Xuan, Y. H., Kang, Y. J., . . . Liu, M. Y. (2016). Serological tools for detection of Trichinella infection in animals and humans. One Health, 2, 25-30. 
